ABDI: Jurnal Pengabdian dan Pemberdayaan Masyarakat ISSN: 2656-369X (Print), 2684-8570 (Online)

Volume 3 No. 2, Desember 2021

http://abdi.ppj.unp.ac.id/index.php/abdi

Email: abdi@ppj.unp.ac.id

DOI: https://doi.org/10.24036/abdi.v3i2.115

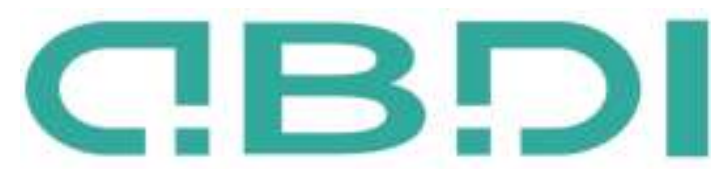

ABDE: JURNAL PENGABDIN DAN PEMBERDAYMN MUSYARAKAT

\title{
Pelatihan Preceptorship Bagi Clinical Instructor Keperawatan
}

\author{
Suci Tuty Putri ${ }^{1}$, Sehabudin Salasa ${ }^{2}$, Lisna Anisa Fitriana ${ }^{3}$ \\ ${ }^{1,2,3}$ Prodi Keperawatan, Universitas Pendidikan Indonesia \\ Email: suci.putri@upi.edu
}

\begin{abstract}
Abstrak
Pengalaman belajar klinik atau lapangan pada pendidikan tinggi keperawatan diperlukan untuk menumbuhkan dan membina kemampuan dan sikap keperawatan profesional. Salah satu cara untuk pengembangan dan pengendalian mutu keperawatan adalah dengan cara mengembangkan lahan praktik keperawatan disertai dengan adanya pembinaan masyarakat professional keperawatan untuk melaksanakan pengalaman belajar di lapangan dengan benar bagi peserta didik. Hal ini dapat dilakukan dengan memfasilitasi kegiatan preseptorship. Program Pengabdian Kepada Masyarakat ini bertujuan untuk meningkatkan kemampuan perawat dalam mendidik mahasiswa dalam memberikan asuhan keperawatan yang aman baik bagi mahasiswa. Metode pelaksanaan kegiatan adalah blended learning, yaitu penyampaian materi online dan pelaksanaan praktek preseptorship secara offline. Jumlah peserta yang terlibat adalah 30 yang merupakan perawat klinik Rumah Sakit dan pembimbing akademik di institusi pendidikan keperawatan di Jawa barat. Progam ini di ikuti oleh seluruh peserta dengan protokol kesehatan. Setelah dilaksanakan pelatihan hasil ratarata skor pengetahuan peserta adalah 78 dan skor rata-rata keterampilan adalah 84. Program ini menunjukkan bahwa perawat sebagai clinical instructor perlu di bekali pemahaman dan keterampilan dalam pelaksanaannya dalam membimbing mahasiswa.

Kata kunci: Blended-learning, Pendidikan klinik keperawatan, Pendidikan keperawatan, Pengabdian kepada masyarakat, Preceptorship

\section{Abstract}

Clinical learning experiences in nursing education are needed to cultivate and develop professional nursing skills and attitudes. One way to establish and control nursing quality is by developing a nursing practice area accompanied by a nursing professional community coaching to carry out the learning experience in the field correctly for students. This can be done by facilitating preceptorship activities. This Community Service Program aims to improve nurses' ability to educate students in providing safe nursing care for students. Implementing the training is blended learning, which is the delivery of online material and offline practice implementation. The number of participants involved was 30 hospital clinical nurses and academic advisors in nursing education institutions. All participants with the Health protocol followed this program. After the training, the participants' average score was 78, and the average score for skills was 84. This program shows that nurses as clinical instructors need to be equipped with understanding and skills to guide students.
\end{abstract}

Keywords: Blended learning, Community service, Nursing clinical education, Nursing education, and Preseptorship

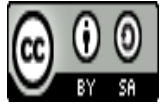

Received: 8 Juni $2021 \quad$ Revised: 3 Agustus $2021 \quad$ Available Online: 26 Agustus 2021 


\section{Pendahuluan}

Tuntutan masyarakat terhadap Kualitas pelayanan keperawatan menjadi masalah paling kompleks saat ini, karena pasien cenderung memiliki harapan yang sangat tinggi dan spesifik terhadap kesembuhan penyakitnya (Laal et al., 2016; Stoyanova, Dimova, Tarnovska, \& Boeva, 2018). World Health Organisation (WHO) telah menetapkan keselamatan pasien sebagai konsep dasar dalam penyediaan layanan perawatan. (Parliament of Sweden, 2010). Secara umum keselamatan pasien telah diterapkan dengan baik di berbagai instansi pelayanan kesehatan hal tersebut terbukti hampir seluruh Rumah Sakit mendapatkan akreditasi dengan predikat paripurna, akan tetapi secara umum para peneliti menemukan hampir 98.000 kasus medical error menyebabkan kematian (Laal et al., 2016). Beberapa instansi Rumah Sakit Pendidikan tidak dapat memingirkan peran penting mahasiswa sebagai elemen penting dalam penerapan keselamatan pasien karena mahasiswa melakukan kegiatan yang sama sebagaimana perawat teregistrasi lakukan, sehingga memerlukan suatu pengawasan dan metoda bimbingan yang baik. Kondisi saat ini materi keselamatan pasien telah diberikan sesuai kurikulum, sedangkan penerapan di lahan praktik mahasiswa terkadang mengalami kesulitan. Kesulitan tersebut disebabkan oleh berbagai faktor seperti kurangnya role model dari pembimbing klinik, bervariasinya cara bimbingan, pelatihan teknis bagi pembimbing klinik, kesepahaman kompetensi yang akan dicapai dalam pembelajaran klinik, fasilitas termasuk sarana dan prasarana yang mendukung proses pembelajaran klinik dan metode pengajaran klinik (AIPNI, 2014).

Menghadapi hal ini perawat baru membutuhkan suatu program bimbingan perawat baru dalam proses adaptasi. Program bimbingan perawat baru dikenal dengan program preceptorship. Preceptorship adalah model pengajaran klinis di mana mahasiswa keperawatan difasilitasi untuk memperoleh kompetensi awal yang memungkinkan mereka untuk berfungsi secara efektif di lingkungan tempat kerja yang kompleks setelah lulus. Pusat dari model ini adalah pembimbing, walaupun mereka mungkin adalah dokter ahli, memerlukan dukungan pendidikan khusus untuk menjalankan peran pengawasan siswa mereka secara efektif (Kamolo, Vernon, Head, \& Toffoli, 2017). Dengan metode preceptorship ini, peserta didik dapat termotivasi karena kesesuaian kompetensi yang dilakukan melalui partisipasi aktif pembelajaran klinik. Sedangkan pemikiran, tindakan dan sikap profesional diperankan oleh pembimbing klinik/clinical instructor (Nursalam, 2015).

Pendidikan klinik merupakan pembelajaran berbasis pengalaman dimana peserta didik diharapkan mampu mengaplikasikan teori yang diperoleh dari akademik pada kasus nyata yang sebenarnya di lahan (Rahmi, Putri, \& Maiszha, 2019) Peserta didik juga diharapkan mampu mengasah ketrampilan sebanyak mungkin dalam melakukan tindakan keperawatan. Menurut Dewey dalam (Reilly Dorothy E \& Marilyn H. Obermann, 2002), masalah utama dalam pembelajaran pendidikan berbasis pengalaman adalah memilih jenis pengalaman yang berdaya guna dan berdaya cipta dalam pengalaman selanjutnya. Pengalaman belajar klinik atau lapangan pada pendidikan tinggi keperawatan diperlukan untuk menumbuhkan dan membina kemampuan serta sikap keperawatan profesional. Salah satu cara untuk pengembangan dan pengendalian mutu keperawatan adalah dengan cara mengembangkan lahan praktik keperawatan disertai dengan adanya pembinaan masyarakat profesional keperawatan untuk melaksanakan pengalaman belajar di lapangan dengan benar bagi peserta didik. Hal ini dapat dilakukan dengan memfasilitasi kegiatan preceptorship.

Program peningkatan kapasitas pembimbing klinik ini merupakan langkah konkrit dalam peningkatan kompetensi peserta didik, yang tak jarang memiliki hambatan diantaranya Perawat dapat memandang mengajar dan mengawasi siswa sebagai beban tambahan, menyita waktu, dan bukan bagian dari peran mereka (Bowles \& Candela, 2005b, 2005a). Oleh karena itu dengan pelatihan peningkatan kompetensi pembimbing klinik ini diharapkan terbentuknya wadah clinical instructor yang fokus melakukan bimbingan ketika ada peserta didik serta dapat menselaraskan antara kopetensi peserta didik sesuai jenjang pendidikan yang dilalui sekaligus dapat melakukan pelayanan keperawatan. Pelatihan preceptorship diperlukan untuk meningkatkan kemampuan perawat dalam mendidik mahasiswa dalam memberikan asuhan keperawatan yang aman baik bagi pasien maupun bagi mahasiswa perawat itu sendiri (patient safety). 


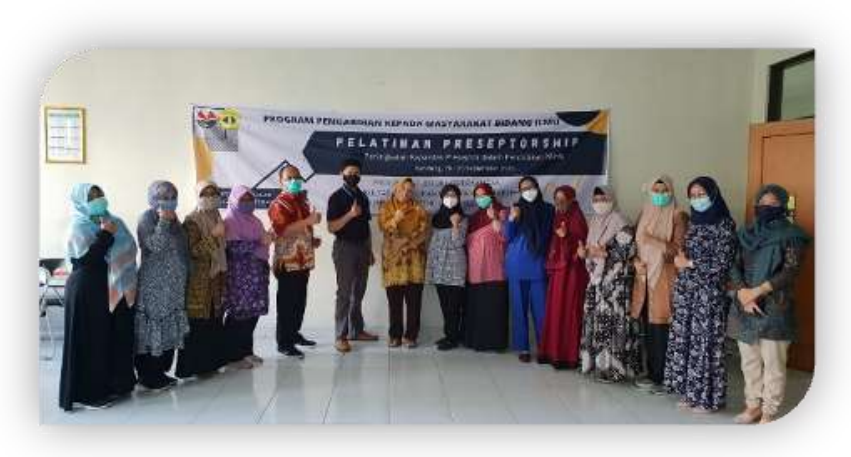

Gambar 1. Pelaksanaan Pelatihan Preceptor

\section{Metode Pelaksanaan}

Pelaksanaan pelatihan ini dilaksanakan dengan memanfaatkan media virtual meeting, fasilitas laboratorium beserta peralatan yang tindakan yang disimulasikan, serta ruang kelas dalam melakukan fase breafing dan debreafing.

Pelaksanaan pelatihan ini menggunakan metode blended learning dengan menyesuaikan dengan kondisi Pandemic Covid-19. Adapun pelatihan ini melalui beberapa tahap:

\subsection{Persiapan}

Persiapan program dilakukan dengan menyusun rencana kegiatan, menyusun draf buku pendidikan klinik keperawatan. Menghubungi narasumber, berkoordinasi dengan RS dan puskesmas serta menyiapakan perlengkapan yang digunakan untuk pelaksanaan program, menyiapkan perlengkapan standar protokol kesehatan Covid-19, serta melakukan koordinasi untuk mendapatkan credit point dari organisasi profesi Persatuan Perawat Nasional Indonesia (PPNI).

\subsection{Pelaksanaan}

Pelaksanaan pelatihan preceptorship yang merupakan Program PKM Berbasis Kepakaran Bidang Ilmu ini dilaksanakan pada tanggal 29-30 September 2020 yang terdiri dari dua tahap diantaranya:

Tahap pertama dilakukan secara full daring dengan metode yang digunakan diantanya: Ceramah dan Diskusi: Metode ini dipilih untuk menyampaikan teori dan konsep yang sangat prinsip dan penting untuk dimengerti serta dikuasai oleh peserta pelatihan. Memberikan pengetahuan tentang pembelajaran klinik. Memberikan pengetahuan tentang peran Clinical Instructor bagi mahasiswa. Memberikan penjelasan tentang kompetensi lulusan mahasiswa DIII dan S1 keperawatan.

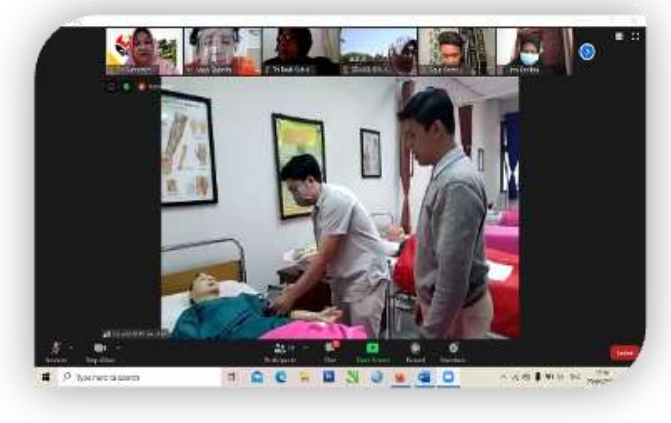

\section{Gambar 2. Sesi Pemaparan materi}

Memberikan pengetahuan terkait permasalahan- permasalahan pembelajaran klinik mahasiswa. Melatih Clinical Instructor dalam mengambil keputusan dalam proses pembelajaran klinik terhadap mahasiswa. Display Study (Foto dan film): Metode ini dipilih untuk menampilkan kondisi dan 
perilaku-perilaku yang mungkin terjadi pada mahasiswa selama praktik. Dengan display study maka para peserta pelatihan akan dapat melakukan pengamatan perilaku mahasiswa dan mempraktekan bimbingan sesuai dengan kondisi mahasiswa.

Tahap kedua dilakukan secara tatap muka dengan berbagai penerapan protokol kesehatan dalam mencegah penyebaran Covid-19 diantaranya pemeriksaan rapid test antibody Covid-19, serta menerapkan 3M.

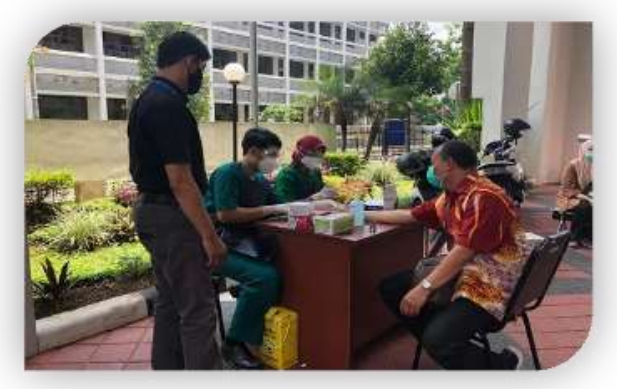

\section{Gambar 3. Penerapan Protokol Kesehatan}

Metode yang dilakukan pada tahap kedua ini diantanya: Role Play; Peserta dibagi berkelompok. Kelompok secara bergantian diminta untuk mempraktekkan model bimbingan preceptorship.

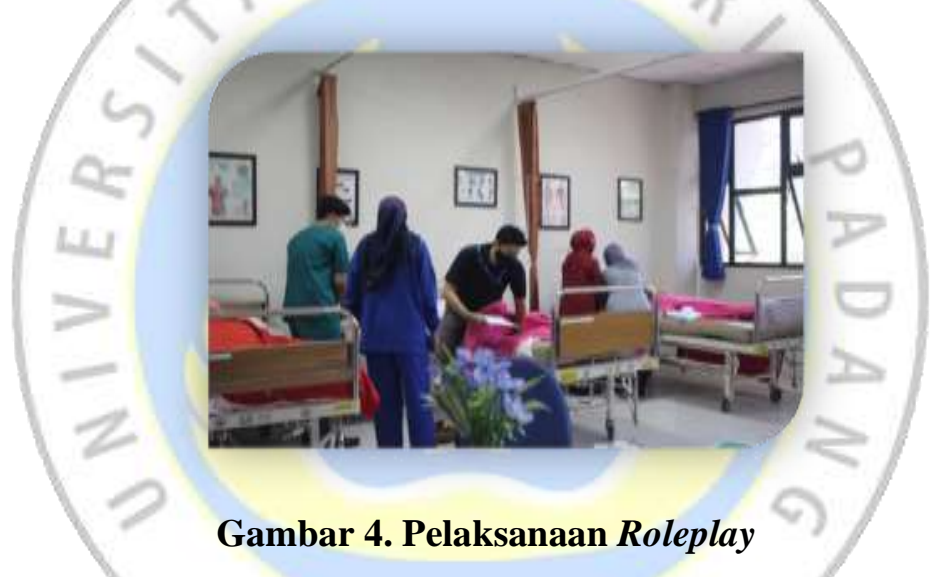

Studi Kasus dan Diskusi; Pada metode ini peserta akan melakukan kajian terhadap kasuskasus yang mungkin dihadapi peserta didik di lahan praktik. Studi kasus dilakukan secara klasikal di ruang kelas.

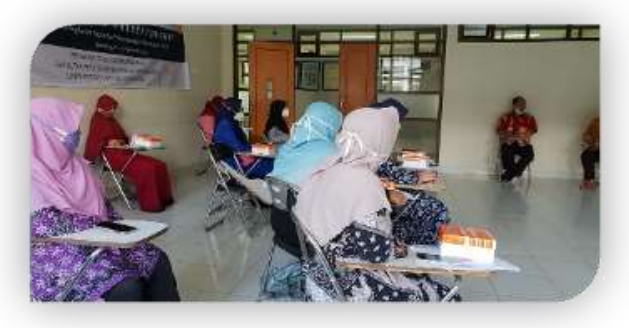

\section{Gambar 5. Studi kasus dan diskusi}

Materi yang diberikan dalam 2 tahap tersebut diantaranya: (1) Metode dan Proses Pembelajaran Klinik, (2) Komunikasi efektif, (3) Metode evaluasi pembelajaran, (4) Metode bimbingan preceptorship, (4) Praktik simulasi membuat Rancangan Aktifitas Belajar dan implementasi preceptorship. 


\subsection{Evaluasi}

Evaluasi pada pelatihan ini dilakukan dengan menggunakan Google Form untuk mengukur pengetahuan peserta, sedangkan untuk mengukur keterampilan bimbingan klinik dilakukan ujian langsung bimbingan klinik di laboratorium dengan melalui tahap breafing, pelaksanaan, dan debrieafing.

\section{Hasil dan Pembahasan}

\subsection{Karakteristik Peserta}

Program ini dilaksanakan kepada 30 orang clinical instructor dari rumah sakit pendidikan dan institusi keperawatan di kota Bandung. Mayoritas peserta adalah pada rentang usia 31-40 tahun, perempuan, Pendidikan terakhir adalah sarjana keperawatan dan lama bekerja lebih dari 5 tahun, karateristik peserta dapat dilihat pada tabel 1 .

Table 1. Karakteristik Peserta $(n=30)$

\begin{tabular}{|c|c|c|}
\hline Karakteristik & f & $\%$ \\
\hline $\begin{array}{c}\text { Umur, tahun } \\
\qquad \quad 20-30 \\
-\quad 31-40 \\
-\quad 41-50 \\
-\quad 51-60\end{array}$ & $\begin{array}{c}5 \\
20 \\
4 \\
1\end{array}$ & $\begin{array}{l}23.1 \\
48.1 \\
26.0 \\
2.8\end{array}$ \\
\hline $\begin{array}{ll}\text { Jenis } & \text { Kelamin } \\
\text { - } & \text { Laki-laki } \\
\text { - } & \text { Perempuan }\end{array}$ & $\begin{array}{c}5 \\
25\end{array}$ & $\begin{array}{l}33.7 \\
66.3\end{array}$ \\
\hline $\begin{array}{cl}\text { Pendidikan } \\
\text { - } & \text { Diploma } \\
\text { - } & \text { Sarjana } \\
\text { - } & \text { Magister }\end{array}$ & $\begin{array}{c}4 \\
18 \\
8\end{array}$ & $\begin{array}{l}22.1 \\
58.7 \\
19.2\end{array}$ \\
\hline 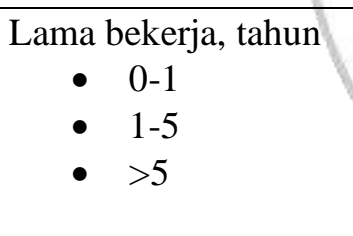 & $\begin{array}{l}1 \\
2\end{array}$ & $\begin{array}{c}24 \\
30.8 \\
45.2\end{array}$ \\
\hline
\end{tabular}

\subsection{Pengetahuan dan Keterampilan Peserta}

Uji pretest dan postest, ujian praktek keterampilan bimbingan klinik dilakukan pada peserta dengan hasil yang tampak pada tabel 2 .

Tabel 2. Rata-rata Pengetahuan dan keterampilan peserta preceptorship $(\mathrm{n}=30)$

\begin{tabular}{lcc}
\multicolumn{1}{c}{ Komponen } & Pretest (min-mak) & Posttest (min-mak) \\
\hline Pengetahuan & $65.8(50-80)$ & $81,3(70-95)$ \\
\hline Keterampilan & - & $84(78-95)$ \\
\hline
\end{tabular}

\subsection{Pembahasan}

Pendidikan klinik merupakan tahapan pendidikan keperawatan yang sangat penting bagi mahasiswa keperawatan dalam mencapai kompetensinya (Carlson \& Bengtsson, 2015; Mårtensson, Löfmark, Mamhidir, \& Skytt, 2016). Prinsip pendidikan klinik dalam mencapai kompetensi tertentu adalah berbasis pengalaman dimana peserta didik diharapkan mampu mengaplikasikan teori yang diperoleh dari akademik pada kasus nyata yang sebenarnya di lahan praktik. Praktik klinik sangat 
penting dalam proses perkembangan kognitif, afektif dan keterampilan sehingga dapat membantu mahasiswa untuk belajar dan menjadi praktisi yang aman dan efektif. (Mårtensson et al., 2016). Dalam pelaksanaan pendidikan klinik, pembimbing di lapangan yang dikenal sebagai Clinical Instructor (CI), yaitu orang yang memegang peranan penting dalam mendampingi dan memfasilitasi belajar mahasiswa di klinik. (Niederriter, JE. et al. 2017). CI merupakan perawat terlatih yang bertanggung jawab atas pembelajaran mahasiswa keperawatan dalam praktik klinis, dan bertugas dalam membimbing, refleksi, umpan balik, penilaian, dan evaluasi mahasiswa. Beberapa studi menjelaskan bahwa untuk menjadi seorang CI, seorang perawat tidak dapat otomatis memiliki kompetensi tersebut, namun hal tersebut didapatkan melalui pelatihan yang intensif (Mårtensson G. 2016; Niederriter, JE. et al. 2017; Dahlke S. 2012).

Beberapa penelitian lain menunjukkan dukungan pendidikan formal maupun non-formal dibutuhkan oleh CI, hal ini berguna untuk mengidentifikasi hubungan antara mahasiswa dan guru, strategi pengajaran mengidentifikasi hubungan interpersonal, kompetensi profesional sebagai pengajar (Dahlke, Baumbusch, Affleck, \& Kwon, 2012; Niederriter et al., 2017). Sedangkan dalam kajiannya Wolf et al (2009) mengidentifikasi hubungan mahasiswa dengan kurikulum pembelajaran yang diterapkan di fakultas merupakan hal yang sangat penting untuk dipelajari Clinical Instructor (CI) baru, dan mereka perlu mengetahui teori pendidikan yang sesuai untuk kelas dan pengaturan klinis (Wolf et al., 2009). Bell-Scriber dan Morton, menyarankan bahwa mendapatkan manfaat dari mendiskusikan tentang hal ini dengan orang lain, yang seringkali lebih berpengalaman dalam melakukan bimbingan klinik serta orang yang dapat memberikan pelatihan bagi CI (Wolf et al., 2009).

Peningkatan kemampuan khusus bagi pembimbing klinis melalui pelatihan preceptorship merupakan jalan penghubung yang dapat menjembatani kemampuan akademis dengan kemampuan klinis mahasiswa (Brehmer \& Ramos, 2014). Hal ini terbukti setelah dilakukan pelatihan preceptorship para pembimbing klinik dapat membedakan cara melakukan bimbingan mahasiswa berdasar jenjang pendidikan serta diupayakan memahami karakter dari mahasiswa yang dilakukan bimbingan (Carlson \& Bengtsson, 2015; Dahlke et al., 2012). Sehingga tujuan utama dalam pelatihan preceptorship ini adalah proses penyamaan persepsi antara kultur akademik dan kultur klinik untuk menghilangkan ketimpangan diantara keduanya.

\section{Kesimpulan}

Kegiatan Pelatihan preceptorship telah dilaksanakan dengan baik. Peserta yang terlibat terdiri dari 30 orang yang berasal dari berbagai institusi RS dan pendidikan di Kota Bandung. Pelatihan dilaksanakan secara blended learning; daring dan luring untuk pencapaian kompetensi. Pelatihan ini penting dilakukan secara regular sebagai bukti pengabdian Prodi Keperawatan UPI dalam memberikan kontribusi terhadap pendidikan keperawatan di masyarakat. Rekomendasi kepada pihak pendidikan akademik dan pendidikan klinik agar menselaraskan kebutuhan belajar pembimbing untuk merancang pendidikan klinik yang tepat.

\section{Daftar Pustaka}

AIPNI. (2014). Materi Pelatihan Preceptorship. Yogyakarta: STIKES Alma Ata.

Bowles, C., \& Candela, L. (2005a). First job experiences of recent RN graduates: Improving the work environment. Journal of Nursing Administration, 35(1), 12. https://doi.org/10.1097/00005110200503000-00006

Bowles, C., \& Candela, L. (2005b). First Job Experiences of Recent RN Graduates. JONA: The Journal of Nursing Administration, 35(3), 33. https://doi.org/10.1097/00005110-20050300000006

Brehmer, L. C. D. F., \& Ramos, F. R. S. (2014). Teaching-service integration: Implications and roles in experiences of undergraduate courses in nursing. Revista Da Escola de Enfermagem, 48(1). https://doi.org/10.1590/S0080-623420140000100015 
Carlson, E., \& Bengtsson, M. (2015). Perceptions of preceptorship in clinical practice after completion of a continuous professional development course- a qualitative study Part II. BMC Nursing, 14(1), 1-7. https://doi.org/10.1186/s12912-015-0092-8

Dahlke, S., Baumbusch, J., Affleck, F., \& Kwon, J. Y. (2012). The clinical instructor role in nursing education: A structured literature review. Journal of Nursing Education, 51(12), 692-696. https://doi.org/10.3928/01484834-20121022-01

Kamolo, E., Vernon, R., Head, A., \& Toffoli, L. (2017). A Critical Review of Preceptor Development for Nurses Working with Undergraduate Nursing Students. International Journal of Caring Sciences, 10(2), 1089.

Laal, F., Fazli, B., Balarak, D., Dalir, F., Mohammadi, M., \& Mirzaei, R. (2016). Attitude toward the Patient Safety Culture in healthcare systems. Patient Saf Qual Improv, 4(2), 363-368.

Mårtensson, G., Löfmark, A., Mamhidir, A. G., \& Skytt, B. (2016). Preceptors' reflections on their educational role before and after a preceptor preparation course: A prospective qualitative study. Nurse Education in Practice, 19(1), 1-6. https://doi.org/10.1016/j.nepr.2016.03.011

Niederriter, J. E., Eyth, D., \& Thoman, J. (2017). Nursing Students' Perceptions on Characteristics of an Effective Clinical Instructor. SAGE Open Nursing, 3(1), 237796081668557. https://doi.org/10.1177/2377960816685571

Nursalam. (2015). Manajemen Keperawatan: Aplikasi dalam praktik Keperawatan Profesional. Jakarta: Salemba Medika.

Parliament of Sweden. (2010). Patientsäkerhetslag (Patient Safety Law).

Rahmi, U., Putri, S. T., \& Máiszha, D. (2019). Tingkat Kepuasaan Mahasiswa DIII Keperawatan Dalam Pembelajaran Klinik. Jurnal Pendidikan Keperawatan Indonesia, 5(2), 184-190. https://doi.org/10.17509/jpki.v5i2.18076

Reilly Dorothy E \& Marilyn H. Obermann. (2002). Pengajaran Klinis dalam Pendidikan Keperawatan (2nd ed.; E. Novieastari, Ed.). Jakarta: EGC.

Stoyanova, R., Dimova, R., Tarnovska, M., \& Boeva, T. (2018). Linguistic validation and cultural adaptation of bulgarian version of hospital survey on patient safety culture (Hsopsc). Open Access Macedonian Journal of Medical Sciences, 6(5), 925. https://doi.org/10.3889/oamjms. 2018.222

Wolf, Z. R., Beitz, J, M., Peters, M. A., \& Wieland, D. M. (2009). Teaching Baccalaureate Nursing Students in Clinical Settings: Development and Testing of the Clinical Teaching Knowledge Test. Journal of Professional Nursing, 25(3), 130-144. https://doi.org/10.1016/j.profnurs. 2008.10.007 